\title{
Obras en la iglesia de San Miguel de Cubillas de Rueda (León)
}

\author{
Construction works in the San Miguel church's \\ of Cubillas de Rueda (León)
}

Jorge MARTÍNEZ MONTERO

Escuela de Arte y Superior de Conservación y Restauración de Bienes

Culturales de León

Recibido: 24-III-2014 / Aceptado: 2-VII-2014

Resumen: A lo largo del presente artículo se pretende dar a conocer el proceso constructivo de la iglesia parroquial de Cubillas de Rueda comprendida entre los años 1562 y 1793, donde hemos documentado la dirección de los maestros de obras de la catedral de León, Juan López de Rojas y Baltasar Gutiérrez, junto a un elenco de entalladores, maestros de carpintería y cantería de primera magnitud en el círculo artístico leonés, como Bautista Vázquez, Rodrigo de Toraja y Francisco Rivas.

Palabras clave: Cubillas de Rueda, León, Juan López de Rojas, Baltasar Gutiérrez, Bautista Vázquez, Rodrigo de Toraja, Francisco Rivas.

ABSTRACT: This article aims to highlight the construction process of the parish church of Cubillas de Rueda between 1562 and 1793, where we have documented the direction of the master builders of the cathedral of León, Juan López de Rojas and Baltasar Gutiérrez, along with a cast of well-known carvers, master carpenters and masons in the leonine artistic circle, as Bautista Vázquez, Rodrigo de Toraja and Francisco Rivas.

Key words: Cubillas de Rueda, León, Juan López de Rojas, Baltasar Gutiérrez, Rodrigo de Toraja, Francisco Rivas.

LA IGLESIA PARROQUIAL DE SAN MIGUEL DE CUBILLAS DE RUEDA Y LA DIRECCIÓN DE JUAN LÓPEZ DE ROJAS EN EL PROCESO DE FÁBRICA DE LA CAPILLA MAYOR

El municipio de Cubillas de Rueda se encuentra situado al noreste de la provincia de León, en la región del Alto Esla. Etimológicamente, Cubillas proviene de un diminutivo de cova o cueva, aludiendo a las primeras moradas de sus habitantes; mientras que Rueda es el determinativo común de los cuarenta y dos lugares que se encontraban bajo la jurisdicción del almirante de Castilla D. Fadrique Enríquez desde el año 1439, mo- 
mento en que recibió el Señorío de los reyes Juan II de Castilla y María de Aragón ${ }^{1}$.

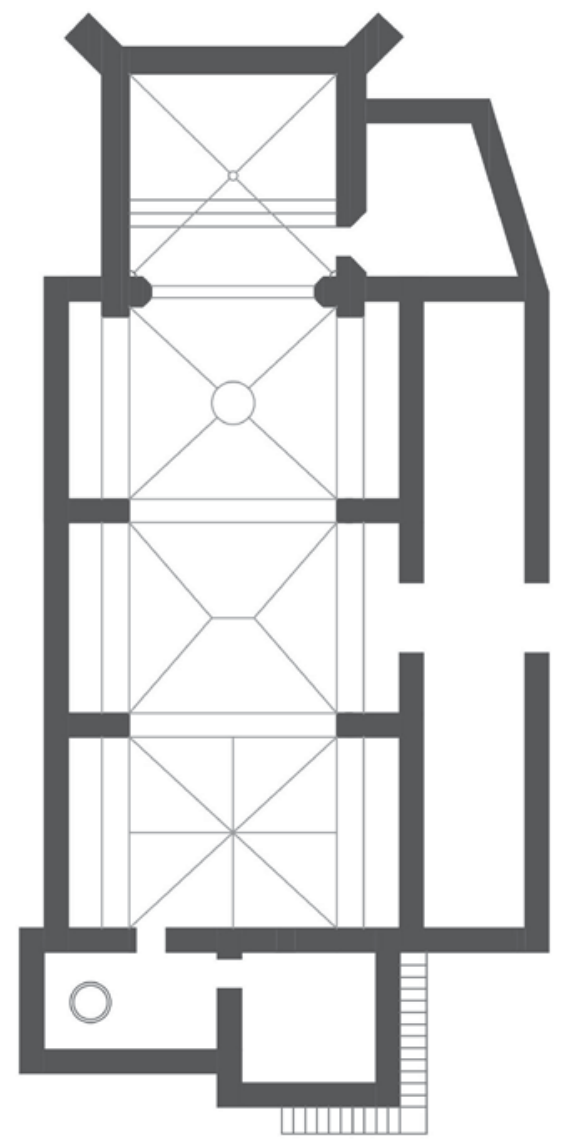

- Fig. 1. Planta de la iglesia de San Miguel de Cubillas de Rueda. Dibujo de Ángela Domínguez Sánchez.

Su iglesia parroquial de San Miguel, de nave única, pórtico lateral, sacristía y torre campanario a los pies, se encuentra enclavada en la zona alta de la localidad y entronca sus comienzos en la construcción de su capilla mayor, una obra llevada a cabo bajo las órdenes de Juan López de Rojas entre los años 1562 y 1572 (Fig. 1)².

1 E. CALVO ALONSO, El Monasterio de Gradefes. Apuntes para su historia y la de algunos otros cenobios y pueblos del concejo, León, 1984, p. 69; E. URDIALES LAREDO, Fueros y privilegios de la comarca de Rueda, León, 1996, p. 74; M. GALLEGO DÍEZ, Historia de la parroquia y el concejo de Quintanas de Rueda, León, 2002, pp. 20-23.

${ }^{2}$ Historiográficamente, el único autor que hemos constatado se preocupó por dar a conocer el discurrir de la villa y sus párrocos, fue el sacerdote de la iglesia D.
Vallisoletano de nacimiento, sus primeros pasos se inician a fines de la década de los cuarenta del siglo XVI como aparejador del templo catedralicio leonés, etapa formativa que se prolonga hasta 1554, cuando llega a ocupar el cargo de maestro de obras tras la muerte de su predecesor, Juan de Badajoz el $\mathrm{Mozo}^{3}$. Impregnado de nuevos ideales clasicistas, hasta el año 1567 lleva a cabo la conclusión del ático del hastial occidental ${ }^{4}, \mathrm{y}$ colabora en la traza del trascoro; magna obra que será materializada por Baltasar Gutiérrez junto a la labor escultórica de Bautista Vázquez, Esteban Jordán y Juan de Juni ${ }^{5}$.

Casado con Ana de Robles, realiza diversas intervenciones en la arquitectura civil y religiosa de la ciudad de León; momento en que la profesora Campos Sánchez-Bordona apunta su participación en la obra del convento de San Marcos hacia $1552^{6}$, mientras que el profesor Rivera Blanco constata su colaboración en 1564 con el maestro Juan del Ribero Rada en el palacio de los Guzmanes,

Fabián Castaño del Riego en sus anotaciones realizadas durante los años 1990 y 1991. F. CASTAÑO DEL RIEGO, Historia de la Parroquia de Cubillas de Rueda, Cubillas de Rueda, 1990-1991. Se trata de una obra mecanografiada de carácter inédito que hemos podido consultar gracias a D. Calixto Sánchez Tejerina, actual párroco de la iglesia de San Miguel, a quien mostramos nuestro agradecimiento por su predisposición y ayuda prestada en todo momento.

${ }^{3}$ J. RIVERA BLANCO, Arquitectura de la segunda mitad del siglo XVI en León, León, 1982, p. 42.

${ }^{4}$ Ibídem, pp. 63-66; M. VALDÉS FERNÁNDEZ, C. COSMEN ALONSO, M. V. HERRÁEZ ORTEGA, M. D. CAMPOS SÁNCHEZ-BORDONA e I. GONZÁLEZ VARAS IBÁÑEZ, Una historia arquitectónica de la Catedral de León, León, 1994, p. 184.

${ }^{5}$ M. D. CAMPOS SÁNCHEZ-BORDONA, "Arquitectura del Renacimiento", en M. VALDÉS FERNÁNDEZ (dir.), Historia del Arte en León, León, 1990, p. 196; M. D. CAMPOS SÁNCHEZ-BORDONA, Juan de Badajoz y la arquitectura del Renacimiento en León, León, 1993, pp. 382-383. Según esta autora, Juan López de Rojas estuvo al frente de la fábrica catedralicia entre los años 1552 y 1558, en colaboración con los maestros Francisco de Villaverde, Bautista Vázquez y Baltasar Gutiérrez.

${ }^{6}$ M. D. CAMPOS SÁNCHEZ-BORDONA, Juan de Badajoz..., pp. 179-180. 
y un año más tarde en la ejecución en la catedral del altar sepulcro de San Pelayo ${ }^{7}$. Es en estos años cuando se hace cargo de las obras del monasterio de Eslonza ${ }^{8}$, coincidiendo con la dirección de la capilla mayor de la iglesia de Cubillas de Rueda; periodo en que le sucede en el cargo catedralicio Baltasar Gutiérrez, maestro que, como veremos, participará años más tarde en la tasación de la sacristía y traza del citado templo parroquial ${ }^{9}$.

La reconstrucción de la historia constructiva de la iglesia ha sido posible gracias a la localización y consulta de los cinco libros de fábrica comprendidos entre los años 1563 y $1989^{10}$.

En el primero de ellos queda constancia del comienzo de las obras en torno al año 1562 por parte del cantero vasco Pedro de Landeta, a quien en junio del año siguiente se pagan diversas cantidades "para en parte de pago y de lo que trabajó en la capilla de la dicha iglesia" y "para en parte de pago del trabaxo y jornales que puso en la obra de la dicha capilla", documentadas a través de diversos descargos de carros de cal, arena y piedra procedente de las poblaciones leo-

${ }^{7}$ J. RIVERA BLANCO, Op. cit., pp. 63 y 179.

${ }^{8}$ M. GÓMEZ MORENO, Catálogo Monumental de España. Provincia de León (1906-1908), tomo I, Madrid, 1925, p. 525.

${ }^{9}$ Su fallecimiento, según Llaguno y Amirola, se produjo en enero de 1572. E. LLAGUNO Y AMIROLA y J. A. CEAN-BERMÚDEZ, Noticias de los arquitectos y arquitectura de España desde su restauración, tomo II, Madrid, 1829, p. 74.

${ }^{10} \mathrm{El}$ Archivo de la iglesia parroquial de Cubillas de Rueda (en adelante AICR) conserva la siguiente documentación: $1^{\circ}$ Libro de fábrica (1563-1616), 2ํㅡㄹ Libro de fábrica (1617-1753), 3ํㅡㄴ Libro de fábrica (1763-1853), $4^{\circ}$ Libro de fábrica (1843-1934) y 5o Libro de fábrica (19351989). En los descargos se anotan los pagos realizados por la iglesia, donde se incluyen los gastos de obra, su ornato y buen funcionamiento de la liturgia diaria (pagos por cera, aceite, óleos, incienso, armar el monumento, ramos de semana santa, lavar y barrer la iglesia entre otros...) incluyendo gastos por la redacción del propio libro de fábrica, así como el subsidio que recibe el mayordomo de la fábrica. nesas de Nava de los Caballeros y Boñar ${ }^{11}$. Oriundo del valle de Arteaga, figura desde 1560 junto al también cantero Marcos de Terliguiz bajo las órdenes del maestro Juan López de Rojas en las obras de la iglesia y claustro del cercano monasterio de San Pedro de Eslonza ${ }^{12}$.

Al citado Marcos Terliguiz, aparejador del monasterio de San Pedro de Eslonza y asentador de la ciudad de León, se le abonan en 1564 seis ducados "por en parte de pago de la obra de la capilla"13. Momento en el que los trabajos debían encontrarse bastante avanzados, por contener en los descargos pagos por la sacada y la traída de ocho

${ }^{11}$ AICR. 1o Libro de fábrica, 2 de junio de 1563, s.f. Mayordomos Francisco Alonso y Pedro de Vega. "Más se les descargan a los dichos mayordomos ciento y quatorçe reales y medio que Pedro Laço en su nombre mayordomo atrasado pagó a Pedro de Landeta cantero vecino de Nuestra Señora de Gautegiç que es en el valle de Arteaga para en parte de pago y de lo que trabajó en la capilla de la dicha iglesia que suman en maravedís trece mill y ochocientos y noventa y tres maravedís de los quales mostró conocimiento. El qual está en este libro al fin dél y enbaxo de otro de veinte mill maravedís que dio Fernando de Segura cantero para en pago de la obra de la dicha capilla".

"Más dio Pedro de Vega mayordomo de descargo quarenta y quatro reales que pagó a Pedro de Landeta cantero para en parte de pago del trabaxo y jornales que puso en la obra de la dicha capilla y piedras del arco que suma mill y quatrocientos y noventa y seis maravedís".

"Más seis reales de la cama de dos canteros de dos meses".

${ }^{12}$ E LLAGUNO Y AMIROLA y J. A. CEAN-BERMÚDEZ, Op. cit., p. 74; M. GÓMEZ MORENO, Op. cit., p. 525; A. CALVO ALONSO, San Pedro de Eslonza, Madrid, 1957, p. 219; J. RIVERA BLANCO, Op. cit., p. 164; M. D. CAMPOS SÁNCHEZ-BORDONA, “El monasterio de San Pedro de Eslonza, modelo de las reformas arquitectónicas de la orden de San Benito en el siglo XVI", Estudios Humanísticos. Geografía, historia, arte, no 13, 1991, p. 281; J. FERNÁNDEZ ARENAS, El monasterio de San Pedro de Eslonza. Sus ruinas y patrimonio disperso, Cistierna, 2012, p. 66.

${ }^{13}$ AICR. 1ํ Libro de fábrica, 25 de mayo de 1564, s.f. Mayordomo Fernando de Verdugo. “Más dieron de descargo seis ducados que pagó Pedro de Vega al cantero Marcos de Terliguiç por en parte de pago de la obra de la capilla de los quales mostró conoscimiento que suman en reales dos mill y doscientos y quarenta y quatro maravedís". 
bolsores y seis repisas, dos capiteles, dos dovelas y una clave para la capilla, incluyéndose la realización de una primera tasación de la obra, desgraciadamente no conservada, por parte de la iglesia y de los citados canteros Landeta y Terliguiz ${ }^{14}$.

Todas estas labores se realizaron actuando como párroco Marcos García Álvarez, a quien le sucede en 1564 Bernardino Conde, bajo el que se produjo el verdadero impulso constructivo de la fábrica. A partir del año 1565 aparece al frente de la capilla otro nuevo cantero, Joanes de Anderica, quien junto a un elenco de oficiales emplea para la obra sesenta y cuatro carros de cantos, trece de cal y treinta de arena, así como unos trescientos carros de piedra de mampostería de Boñar, La Debesa y Las Arrimadas $^{15}$.

${ }^{14}$ Ibídem, 17 de mayo de 1565, s.f. Mayordomo Fernando de Verdugo. "Más dio de descargo dos ducados que pagó de parte de la iglesia a los oficiales y canteros que tasaron la obra de la capilla y piedras labradas por mandamiento del señor provisor. Por poner cera por la declaración de la dicha tasación que aquí queda cosida".

"Más otros dos ducados que pagó a los dichos tasadores en nombre de los canteros que hiçieron la dicha capilla los quales mandó el señor provisor pagar como paresciera por la dicha tasación y escriptura que aquí queda cosida".

${ }^{15}$ Ibídem, 15 de mayo de 1566, s.f. Mayordomo Fernando de Verdugo. "Más dio de descargo el dicho mayordomo Fernando de Verdugo, quatrocientos y veinte y siete reales que pagó a Joanes de Anderica cantero y a sus oficiales para en pendiente de pago de la capilla que hace de la dicha iglesia de los quales mostró conoscimientos que son quatro como parescerá por ellos que quedan en el libro borrador, los quales suman".

Ibídem, 5 de junio de 1567, s.f. Mayordomos Antonio Andrés y Pedro de Pendones. "Más dio de descargo el dicho mayordomo Antonio Andrés veinte y tres mill y seiscientos y dieç y siete maravedís que pagó a Joannes de Enderica cantero para en parte de pago de la obra de la capilla que hace para la dicha iglesia de los quales mostró conoscimientos que eran dieç los quales quedan en el libro de memoria de la iglesia y rubricas de mi mano como pagados en cuenta".

"Y luego hiço rebeer las pagas que los maiordomos han hecho a Marcos de Derica y sus compañeros en quenta de la capilla y por siete pagas y partidas pagadas en este libro parece que an recibido sesenta y seis mill y quinientos y dieç y ocho maravedís".
Joanes de Anderica o Enderica, según se recoge en los mandamientos otorgados por el visitador de la fábrica, "tiene tomada a haçer la capilla desta iglesia que conforme al contrato que está en este libro la abia ya de aber ya çerrado a dos años y aun que la iglesia tiene muchos materiales al pie de la obra no quiere entender en ella sino es en algunos inviernos muy pocos días quando yela y no se puede labrar con cal, por lo qual la obra forçosamente a de salir faltosa y las fianças que tiene dadas no bastan e tiene reçebidos muchos maravedís, reçibe mucho daño la iglesia"16.

De este dato se desprende la problemática surgida con el cantero por dilatar más de dos años la finalización de las obras, a quien se acusa de trabajar cuando hiela, con el consiguiente peligro de que la capilla quede mal construida. El señor visitador manda que el cura y mayordomo de la fábrica no le paguen hasta que no avance en la obra y se le recuerda que en quince años no puede aparecer "abertura ni sentimiento alguno" y tiene que terminarla para el mes de agosto de $1567^{17}$.

Otro de los testimonios que hemos localizado alude al primer inventario de la iglesia, fechado en el año 1567 y del que extraemos la existencia en la iglesia de un primer "retablo de talla y pintura en el altar mayor con la imagen de Nuestra Señora y Señor San Miguel e un crucifijo con dos imágenes de bulto"18. Nada se ha conservado de esta obra renacentista, a excepción de las imágenes originarias del calvario -la Virgen y San Juan- que pasaron a rematar el actual retablo principal de la iglesia, una obra realizada por iniciativa del párroco Francisco Morán entre 1732 y $1763^{19}$.

${ }^{16}$ Ibídem, junio de 1567, s.f. Mayordomo Pedro de Pendones. (Documento $\mathrm{n}^{\mathrm{o}} 1 \mathrm{del}$ apéndice documental).

${ }^{17}$ Ibídem.

${ }^{18}$ Ibídem. Mayordomo Antonio Andrés.

19 Según reza en la inscripción de la predela del retablo "HYZOSE... ESTA OBRA A HOMRIA, Y GLORIA DE DIOS NUESTRO SEÑOR Y DE SU... SIENDO CURA DE ESTE LUGAR D. FRANCISCO MORÁN, AÑO 17(63)". 
Volviendo a la labor de fábrica de la capilla, durante los descargos del año 1569 se siguen anotando partidas a los canteros, incluyéndose cantidades de viajes "en ir a León ciertos caminos, citado por los canteros sobre la obra de la capilla" ${ }^{\prime 20}$. Tales viajes se efectuarían para ratificar la correcta marcha y dirección de las obras.

Documentalmente, el único testimonio sobre la obra publicado hasta la fecha, vio la luz en el año 1982 por Rivera Blanco, quien recoge un documento conservado en el Archivo Histórico Diocesano de León y fechado el 12 de octubre de 1570, en el que aparece por primera vez el maestro Juan López de Rojas a cargo de las obras de la iglesia, nombrando como supervisor de las mismas a Juan de Lezica "aparexador de la obra de señor San Pedro de Aslanza" 21 . Tras su consulta y posterior transcripción, constatamos que este cambio se produjo con motivo del fallecimiento de los canteros Enderica y Terliguiz ${ }^{22}$, quienes habían levantado "los cimyentos y partes de paredes hasta los capiteles de la capilla mayor de la dicha yglesia"; obligándose Rojas y Lezica quienes "haremos y acabaremos de haçer la dicha capilla hasta la poner en perfeccion de suerte que esté acabada en lo que toca a la cantería a vista de oficiales nombrados los unos por parte de la dicha iglesia y los otros por parte de nos los dichos oficiales" 23 .

${ }^{20}$ AICR. 1ํㅡㄹ Libro de fábrica, 16 de octubre de 1569 , s.f. Mayordomo Juan de Valdeón.

${ }^{21}$ Juan de Lezica se intitula aparejador del monasterio burgalés de San Pedro de Arlanza, y no de Eslonza como afirma Javier Rivera. J. RIVERA BLANCO, Op. cit., p. 165. El documento aparece de nuevo citado en: G. CARRIZO SAINERO, "Las fuentes de información para el estudio del escultor Bautista Vázquez "el leonés", Boletín Millares Carlo, no 12, 1993, p. 178.

${ }^{22}$ Un joven Juan de Lezica o Licica aparece entre el elenco de oficiales de cantería que trabajaron en el claustro catedralicio junto al maestro Juan de Badajoz el Mozo a partir del año 1539, y como asentador entre los años 1548 y 1551. J. RIVERA BLANCO, Op. cit., p. 59; M. D. CAMPOS SÁNCHEZ-BORDONA, Juan de Badajoz..., pp. 178-179.

${ }^{23}$ Archivo Histórico Diocesano de León (en adelante AHDL). Protocolo de Juan Fernández de Vega, legajo
Entre las condiciones estructurales de la fábrica afirman que la obra de la capilla "será fuerte y firme" estableciendo como garantía una vez terminada el hecho de que "sobre ella se pueda cargar la madera de la dicha capilla e texado della dentro de un año de la firma desta carta", estipulándose la necesidad de sufragar por parte de la iglesia el coste de los materiales necesarios para su finalización ${ }^{24}$.

Continuando con el primero de los libros de fábrica de la iglesia, todavía en 1571 se anotaban partidas del año anterior destinadas a pagar a Joanes de Enderica, momento en que se realiza una segunda tasación de la obra y comienzan a incluirse otras nuevas del citado "Joannes de Leçica cantero para en pendiente de pago de la obra de la dicha capilla" ${ }^{25}$, junto a sucesivos descargos de materiales entre los que se incluyen carros de cal, arena, madera y más de cien carros de piedras de Nava de los Caballeros, Las Bodas, Argovejo y Vidanes ${ }^{26}$. Durante

14, caja 9, 12 de octubre de 1570, s.f. Mayordomo Juan de Valdeón. "Sepan quantos esta pública escritura vieren como nos Juan Lópeç de Roxas maestro de la obra de la santa yglesia de León e yo Juan de Leçica aparexador de la obra de señor San Pedro de Aslanza vecinos de la cibdad de León como prenda deudores y portadores e yo Bautista Bazquez escultor vezino de la cibdad de León como vuestro fiador en prenda propia cumplidor y portador todos tres juntamente... otorgamos e conoçemos por esta presente carta que nos obligamos por nuestras personas bienes muebles y rayçes ávidos e por aber de que demos de la obra que la iglesia parroquial de señor San Miguel del lugar de Cubillas de Rueda tienen encomendada haçer Marcos de Terliguiz e Juanes de Enderica canteros defuntos..." (Documento $n^{\underline{0}} 2$ del apéndice documental).

${ }^{24}$ Ibídem, s.f.

${ }^{25}$ AICR. 1ํㅡㅁ Libro de fábrica, 6 de junio de 1571, s.f. Mayordomo Francisco Rodríguez. “Más dio de descargo dieç y seis reales y medio que pagó por el dicho Joannes de Enderica cantero de la tasación de la dicha capilla y mostró conoscimiento dellos que suman".

"Ojo desde esta partida entra el recibo de Joannes de Leçica".

"Más dio de descargo el dicho mayordomo Juan de Valdeón veinte y seis ducados y real y medio que dio y pagó al dicho Joannes de Leçica cantero..."

${ }^{26}$ Ibídem, 11 de febrero de 1572, s.f. Mayordomo Pedro Lazo. "Más ciento e deçiseis reales que dio a Joanes 
los años siguientes figuran nuevos pagos a Lezica que se encontraría cubriendo la capilla mayor, tal y como se deduce del hecho de que se destinen "veinte y ocho maravedís de vino con que combidar a los que ayudaron a subir la clave de la capilla" y "de haçer los andamios para armar los cruçeros para la capilla y arcos cinco reales y medio" (Fig. $2)^{27}$.

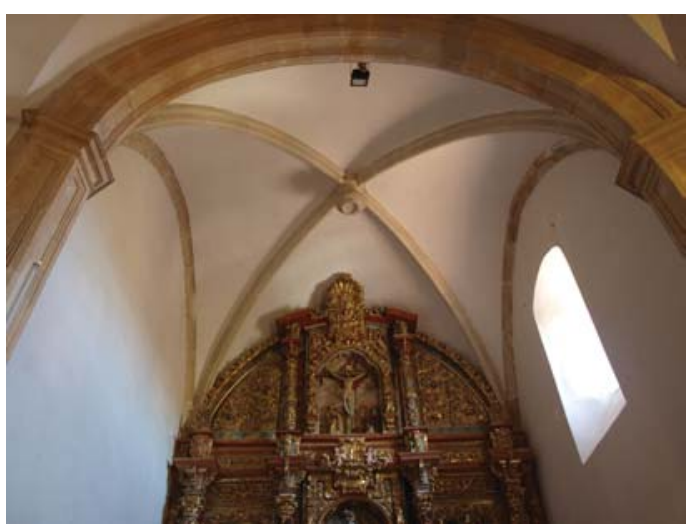

- Fig. 2. Vista interior de la bóveda de crucería y arco de apertura de la capilla mayor de la iglesia de San Miguel de Cubillas de Rueda. Foto del autor.

Finalmente, como se estipulaba en el contrato de obra y tras el fallecimiento de López de Rojas en 1572, se llevó a cabo el cerramiento de la capilla por parte de oficiales, obreros y carpinteros bajo las órdenes del aparejador del monasterio burgalés Juan de Lezica, anotándose importes por "cortar madera y retexar y cerrar la capilla mill y quatrocientos y un maravedís" 28 .

de Laçica cantero, mostró conoscimiento de ellos".

${ }^{27}$ Ibídem, 18 de junio de 1572, s.f. Mayordomo Pedro Lazo. "Más quatro reales que dio a Juanes de Leçica cantero para sacar la tova para la capilla".

"Más dos reales de traer y cortar dos carros de madera para los andamios de la capilla".

${ }^{28}$ Ibídem, 4 de julio de 1573, s.f. Mayordomo Santiago Simón. "Más se le descargan quatrocientos y dieç y seis maravedís de carne y pescado y sardinas y otras cosas que gastaron con los que ayudaron a cubrirse la capilla y los mesmos oficiales".

"Más ochocientos y sesenta y nueve maravedís que se gastaron de pan con los oficiales y algunos obreros que cubrieron la capilla".
Este hecho se ratifica en el descargo de 1574 con la existencia de una nueva tasación de la capilla "que en esta iglesia hiçieron Joan López de Rojas y Marcos de Denderica canteros", anotada durante las visitas de D. Juan Gutiérrez de Villanueva, arcipreste de Cervera y visitador del obispado leonés, por la que ambos maestros estiman la hechura de la capilla en ciento treinta y tres mil maravedís ${ }^{29}$. A continuación, aprovechando la colocación de los andamios en el interior del templo, el bachiller manda que se blanquee la capilla "sin pintura ni pinçel alguna porque sea a menos costa y más vistosa”, a la vez que se quite "la pared que está entre la iglesia y la capilla y que se hagan quatro o cinco gradas vien hechas y sobre ellas el altar mayor que esté alto y preheminente de doçe palmos de largo y que se pase el retablo y se asiente luego en la dicha capilla y se diga misa en ella".

Esta última anotación nos proporciona una información muy detallada acerca de la finalización de las obras, evidenciadas por la conexión entre la capilla y el primer tramo de la iglesia, junto al traslado a la misma del retablo principal; trabajos por los que se gastaron un total de once du$\operatorname{cados}^{30}$. Esta labor se completó con la realización en 1575 de un caedizo o tejadillo saliente de la iglesia por un carpintero cuya obra fue tasada en ciento veinticinco reales (Fig. 3) $)^{31}$.

${ }_{29}$ Ibídem, 17 de marzo de 1574, s.f. Mayordomo Antonio Martínez. Primera visita del bachiller D. Juan Gutiérrez de Villanueva. (Documento n⿳o 3 del apéndice documental).

Ibídem, 8 de noviembre de 1576, s.f. Mayordomo Andrés Verdugo. Segunda visita del bachiller D. Juan Gutiérrez de Villanueva. (Documento n⿳o 4 del apéndice documental).

${ }^{30}$ Ibídem, 7 de junio de 1574, s.f. Mayordomo Alonso de Amor. "Más de blanquear la capilla açer los altares y gradas y quitar el retablo y poner onçe ducados a los oficiales".

${ }^{31}$ Ibídem, 27 de julio de 1575, s.f. Mayordomo Alonso de Amor. 


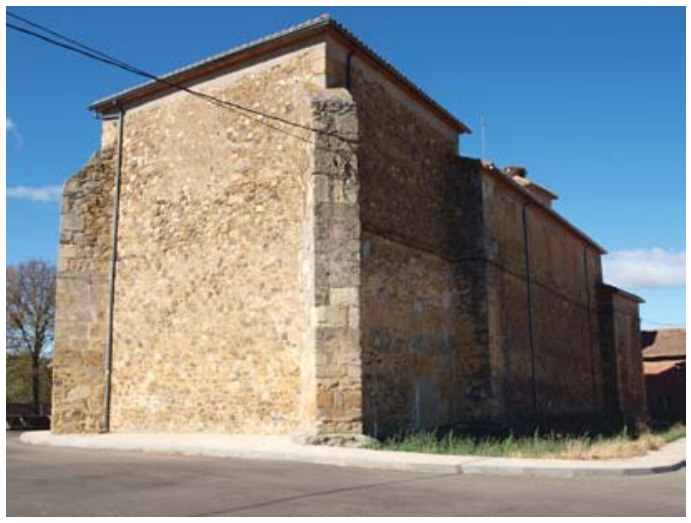

- Fig. 3. Vista exterior de la capilla mayor de la iglesia de San Miguel de Cubillas de Rueda. Foto del autor.

En estos momentos y dándose por concluida la labor de cantería de la capilla, comienzan a liquidarse cantidades pendientes a Ana de Robles, viuda del maestro López de Rojas, quien cuatro años después de su muerte recibe importes por valor de doscientos reales en $1576^{32}$, doscientos treinta y un reales en $1577^{33}$, treinta y tres ducados y cuatro reales en $1578^{34}$, ciento cuarenta y nueve reales en $1580^{35}$, y por último, ciento

32 Ibídem, 17 de julio de 1576, s.f. Mayordomo Pedro Bueno de Arriba. "Primeramente dio de descargo el dicho mayordomo que avía gastado en pro de la iglesia doscientos reales que dio y pagó a Ana de Robles viuda veçina de León como muger de que quedó y heredera de Juan López maestro de la obra desta capilla para en pendiente de pago de la dicha capilla, de los quales mostró cognoscimiento que por mi queda chancellado, que suman".

${ }^{33}$ Ibídem, 3 de julio de 1577, s.f. Mayordomo Andrés Verdugo. "Más se le descargan al dicho mayordomo Andrés Verdugo doscientos y treinta y un reales que dio y pagó a Ana de Robles y a su yerno Lope Costilla veçino de León para en pendiente de pago de la obra de la capilla de la iglesia de los quales mostró cognoscimiento que por mí quedan chancellado..."

${ }^{34}$ Ibídem, 15 de julio de 1578, s.f. Mayordomo Andrés Verdugo. "Primeramente dio de descargo el dicho mayordomo treinta y tres ducados y quatro reales que dio y pagó a Lope Costilla veçino de León y cobrador de Ana de Robles veçina de León para en pago de la obra de la capilla de que mostró cognoscimiento que por mí queda chancellado suman doce mill y quinientos y onçe maravedís".

${ }^{35}$ Ibídem, 18 de junio de 1580, s.f. Mayordomo Andrés Verdugo. "Primeramente dio en descargo el dicho cincuenta y cuatro reales, dos cargas de trigo y siete cargas de centeno en $1581^{36}$.

De la misma manera, durante los años 1579 y 1580, constatamos pagos pendientes a los canteros fallecidos Juan de la Cidra y Marcos de Terliguiz, éste último a través del cantero Marcos Denderica ${ }^{37}$. Cantidades que, con motivo de la visita a la iglesia del licenciado Luis de Rabanal, el mayordomo Juan de Vega anota por un importe de mil catorce maravedís de más, por lo que se le condena a que los pague a la iglesia "e los cobre del susodicho Fernando Fernándeç (mayordomo del año 1580) y en las primeras quentas que sean tomadas se le carguen juntamente" ${ }^{\prime 38}$.

Finalmente, los descargos de 1583 y 1584 reflejan partidas de cal, arena, barro y

mayordomo ciento y quarenta y nueve reales que pagó Ana de Robles muger de Juan López de Roxas cantero para en pago de la capilla mostró conocimiento".

${ }^{36}$ Ibídem, 19 de julio de 1581, s.f. Mayordomo Fernardo Fernández. "Primeramente dio de descargo el dicho Fernardo Fernándeç dos cargas de trigo que dio a la dicha Ana de Robles mujer de Juan López de Rojas cantero para en pago de la capilla de que mostró conocimiento que queda cancellado".

"Más de siete cargas de centeno que dio a la dicha Ana de Robes para la dicha quenta".

"Más ciento y cinquenta y quatro reales que dio a la dicha Ana de Robles para la dicha quenta de que mostró conoscimiento que queda cancellado".

${ }^{37}$ Ibídem, 10 de julio de 1579, s.f. Mayordomo Andrés Verdugo. "Más dio de descargo el dicho mayordomo mill y ochoçientos y treinta maravedís que dio y pagó a Francisco de Corniero veçino de Palacio en nombre de Juan de la Cidra cantero con lo qual se pagó lo que se averiguó deverle la iglesia en el tiempo que trabajó en la iglesia su parte y se le acabó de pagar de que mostró cognoscimiento".

Ibídem, 18 de junio de 1580, s.f. Mayordomo Andrés Verdugo. "Más cinquenta y nueve reales y catorçe maravedís di yo y un quarto que suman y pago a Marcos Denderica el qual los cobró en nombre de Marcos Ibáñez de Terliguiz para en pago de la capilla".

${ }^{38}$ Ibídem, 15 de noviembre de 1581, s.f. Mayordomo Juan de Vega. "De manera que tienen rescevido de más los dichos canteros de los çiento y treinta y tres mill maravedís en que fue tasada la dicha capilla mill y catorce maravedís según se tomó cuenta y paresçe por las pagas que se an hecho a los dichos canteros". (Documento $\mathrm{n}^{\mathrm{o}} 5$ del apéndice documental). 
maderos traídos desde la cercana localidad de Quintana del Monte, junto a clavos, clavijas y un pago por valor de ciento cincuenta y tres reales empleados en los cuarenta y tres jornales necesarios para el retejo y caedizo de la iglesia ${ }^{39}$.

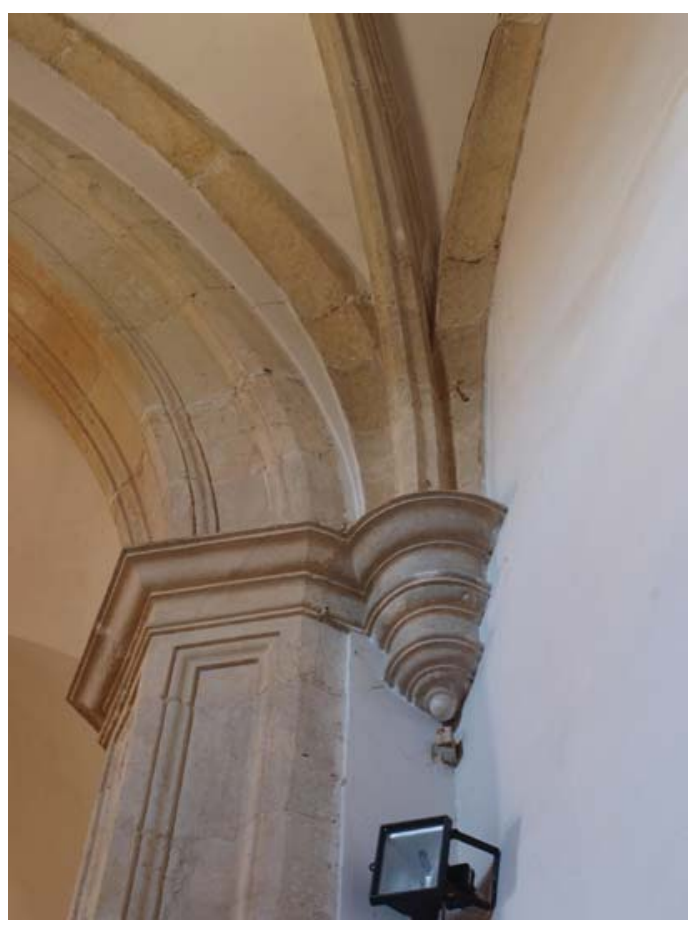

- Fig. 4. Detalle de una de las mesetas semicirculares sobre ménsula en el abovedamiento interior de la capilla mayor de la iglesia de San Miguel de Cubillas de Rueda. Foto del autor.

El resultado es el de una capilla de planta cuadrangular, con contrafuertes exteriores y cubierta con bóveda de crucería cuyos nervios descansan en cuatro apoyos de mesetas semicirculares sobre ménsulas; motivos ornamentales iniciados por el maestro Juan de Badajoz en la sacristía del convento de San Marcos (1538-1549) y que

${ }^{39}$ Ibídem, 1 de septiembre de 1583, s.f. Mayordomo Andrés Lazo. "Primeramente dio descargo el dicho Andrés Laço mayordomo de lo que avía gastado en pro de la iglesia ciento y cinquenta y tres reales de quarenta y tres jornales que se pusieron en el retejo y caediço de la iglesia que se hiço con liçençia del señor provisor".

Ibídem, 3 de julio de 1584, s.f. Mayordomo Andrés del Moral. "Iten dos reales de cerrar el caedizo porque no entrasen las golondrinas". acaban siendo muy habituales en la arquitectura leonesa del quinientos (Fig. 4). Mientras que otro de los recursos más empleados por artistas del último tercio del siglo, de la talla de Juan del Ribero Rada o Felipe de la Cajiga, es el arco de medio punto que hace de unión con la iglesia; cuya rosca y pilastras cajeadas presentan notables similitudes con el que enmarca la capilla de los Villafañe en el convento de San Agustín en Mansilla de las Mulas (1572-1587) ${ }^{40}$.

Este tipo de ménsulas, de estirpe plateresca tardía, acaban casando perfectamente con el gran arco de triunfo de corte clasicista, aunando en un mismo espacio dos gustos estéticos contrapuestos.

\section{LA OBRA DE LA SACRISTÍA Y CAJO- NERÍA DE LA IGLESIA: LAS TASA- CIONES DE BALTASAR GUTIÉRREZ Y BAUTISTA VÁZQUEZ}

El proceso de fábrica del templo parroquial continúa en este momento con la construcción de la sacristía, una obra levantada por iniciativa del obispo de León, D. Francisco Trujillo, quien durante la visita a la iglesia el 5 de octubre de 1584 manda "se haga una sacristía en la dicha iglesia del tamaño y en la parte que al dicho rector e mayordomo e feligreses mejor bieren que conbiene... e de a haçer a destajo o jornal como mejor bieren que conviene a la persona a que para ello tenga liçençia de su señoría" ${ }^{41}$.

En este caso, la obra se adjudica al cantero Diego del Pando y al carpintero Gonzalo de la Cidra, quienes se encuentran al cargo de la misma desde finales del año 1584, cuando comienzan a anotarse des-

${ }^{40}$ C. ROBLES DÍEZ, Reseña histórica de Mansilla de las Mulas, León, 1924, pp. 80-81; L. ÁVAREZ RODRÍGUEZ, Mansilla de las Mulas, monasterios y pueblos colindantes, León, 1981, pp. 75-76.

${ }^{41}$ AICR. $1^{\circ}$ Libro de fábrica, 5 de octubre de 1584, s.f. Mayordomo Andrés del Moral. Visita del obispo de León D. Francisco Trujillo. 
cargos de materiales para la sacristía ${ }^{42}$; sucediéndose pagos sucesivos de cantidades durante los años 1586, 1587, 1588, 1590 y $1591^{43}$. Una obra que fue tasada por el maestro de obras de la catedral, Baltasar Gutiérrez $^{44}$, quien había sido aparejador de Juan López de Rojas hasta aproximadamente el año 1563, y que le sucede al frente de las obras catedralicias en 1572, prolongándose en el cargo hasta su muerte, acaecida en el año $1608^{45}$.

Mientras se acomete la obra de la sacristía, se lleva a cabo el encargo de la cajonería de la iglesia, siendo el entallador Bautista Vázquez "el Leonés" el encargado de

${ }^{42}$ Ibídem, 12 de julio de 1585, s.f. Mayordomo Francisco Rodríguez. "Iten sesenta reales que dio a los carpinteros para en pago de la obra".

"Iten a los canteros sesenta y seis reales y veinte y dos maravedís en dinero y tres fanegas de trigo y media de centeno para en pago de la cantería de la sacristía".

${ }^{43} \mathrm{Ibídem}, 3$ de junio de 1586, s.f. Mayordomo Pedro de Pendones. "A Diego del Pando cantero veçino de la ciudad de León por raçón de la sacristía que hiço en la iglesia parrochial de este lugar de Cobillas lo qual me consta sea todo treinta y quatro ducados y seis maravedís".

"Más se le descargan ciento y dieç y seis reales que dio y pagó a Gonzalo de la Cidra carpintero... con los quales acabó de pagar al dicho Gonçalo de la Cidra la obra de carpintería que hiço en la sacristía".

Ibídem, 10 de septiembre de 1587, s.f. Mayordomo Pedro Alonso. “Más treçe reales y medio que dio a Diego de Pando cantero para sacar piedras con que se haga la obra que tiene a su quenta.

Iten dos ducados... que dio a Diego de Pando cantero para façer la obra de la iglesia".

Ibídem, 4 de agosto de 1588, s.f. Mayordomo Juan Rodríguez. "Primeramente dio en descargo este mayordomo veinte y un mill y duçientos y cinquenta y ocho maravedís que pagó a Diego del Pando cantero por la obra que ba haciendo en la iglesia".

Ibídem, 1 de agosto de 1591, s.f. Mayordomo Alonso del Cantorel.

${ }^{44}$ Ibídem, 3 de junio de 1586, s.f. Mayordomo Pedro de Pendones. "Más seis reales digo tres que gastó con Baltasar Gutiérrez maestro de labra de Regla quando bió y tasó la sacristía de esta iglesia". Lamentablemente no conservamos la citada tasación por faltar varias hojas en el libro de fábrica.

${ }^{45}$ La sacristía actual fue construida por el maestro Fernando del Reguero en 1844. su materialización, tarea por la que recibe diversas cantidades y que acaba tasando en 1589 por trescientos noventa y ocho reales, coincidiendo con su colocación en la sacristía ${ }^{46}$. Este escultor, de origen francés y autor de diversas obras en el foco catedralicio entre los años 1563 y 1577, junto a maestros de la talla de Juan de Angers o Juan de Juni, es quizá uno de los artistas menos conocidos del renacimiento leonés, autor de cajonerías de nogal en las iglesias parroquiales de Marne o Sahelices del Payuelo, y de numerosas tasaciones y hechuras de esculturas, custodias y retablos por toda la geografía leone$\mathrm{sa}^{47}$.

${ }^{46} \mathrm{Ibídem}, 12$ de julio de 1585, s.f. Mayordomo Francisco Rodríguez. "Iten dio en descargo catorçe ducados que pagó a Batista Báçqueç entallador para en parte de pago de los cajones que hace para la iglesia mostró conoscimiento".

Ibídem, 13 de marzo de 1589, s.f. "Tasación del escultor Bautista Baçqueç de los cajones de talla que hizo".

"Los caxones que están fechos para la yglesia parroquial del lugar de Cubillas tierra de Rueda tienen de largo ocho pies la obra que llevan en quatro caxones, los dos cada uno de a cinco pies y medio de largo, los otros a tres pies y medio cada uno, a un lado destos caxones está una alaçena, tiene la mesa de cubierta de nogal sobre ella... suma la madera de estos caxones ciento e siete reales los jornales son sesenta e quatro y medio contado cada uno a quatro reales suma ducientos cinquenta y ocho reales más en él el trabajo del cristo con su cruç calbario como está treinta y tres reales. Esto es lo que fallo conciencia a lo que Dios nuestro señor me da a entender".

Ibídem, 1 de agosto de 1591, s.f. Mayordomo Alonso del Cantorel. "Más dio a Bautista Báçqueç escultor veçino de León para en parte de pago de los caxones que hiço çiento y dieç y siete reales y medio como pareçió por su carta de pago fecha en veinte y dos de diciembre de nobenta años".

Ibídem, 7 de agosto de 1589, s.f. Mayordomo Luis Hernández. "Más dos reales y doçe maravedís de la tasaçión de los caxones".

"Más treçe reales de traer los caxones de León en dos carros".

"Más tres reales que hiço de costa el que assentó los caxones".

"Más siete mill y treçientos y çinquenta y dos maravedís que pagó a Bautista Baçqueç entallador por los caxones que hiço en la dicha iglesia... mostró conocimiento y fue chançellado".

${ }^{47}$ G. CARRIZO SAINERO, Op. cit., pp. 169-184. 
Dicha cajonería fue compuesta y pintada en varias ocasiones durante los años 1772, 1776 y $1849^{48}$, sustituyéndose por la actual que se compró por 1.000 pesetas en $1948^{49}$.

\section{EL MAESTRO RODRIGO DE TORAJA Y LA TRAZA DE BALTASAR GUTIÉ- RREZ PARA LA CONSTRUCCIÓN DE LA NAVE DE LA IGLESIA}

El 6 de noviembre de 1592 tiene lugar, por orden del obispo D. Francisco Trujillo, la visita del licenciado Olmos a la iglesia, quien ante la falta de oficial al frente de la fábrica, insta al rector y mayordomo a que "busquen un buen offiçial de cantería que acave la dicha obra" ${ }^{\prime 50}$. Este hecho deja constancia de la paralización de las obras y evidencia el nuevo apoyo del prelado leonés a la iglesia, en esta ocasión de la mano del maestro de cantería y carpintería Rodrigo de Toraja, encargado de levantar el cuerpo principal entre los años 1595 y $1602^{51}$.

${ }^{48}$ AICR. $3^{\circ}$ Libro de fábrica, 9 de julio de 1772, s.f. "Iten veinte reales de las tablas para componer los cajones".

Ibídem, 20 de junio de 1776, s.f. "Más ciento y sesenta reales que llevó el tallista que compuso los cajones y altares".

Ibídem. $4^{\circ}$ Libro de fábrica, 6 de marzo de 1849, s.f. "Iten pintar el calvario, las puertas de las crismeras y sobre los cajones de la sacristía veintidós reales".

${ }^{49}$ Ibídem. $5^{\circ}$ Libro de fábrica, 1 de enero de 1948, s.f. "De una cajonería para la ropa mil pesetas".

${ }^{50}$ Ibídem. $1^{\circ}$ Libro de fábrica, 6 de noviembre de 1592 , s.f. Visita del licenciado Olmos, visitador por el obispo de León Francisco Trujillo.

${ }^{51}$ Ibídem, 17 de mayo de 1595, s.f. Mayordomo Andrés Díez. "Primeramente da por descargo el dicho Andrés Díeç mayordomo que pagó a Rodrigo de Toraja ofiçial de carpintería para en pago de la obra que hace en la iglesia cinquenta ducados y dos reales que valen en maravedís dieç y ocho mill y ochoçientos y dieç y ocho maravedís, mostró carta de pago".

"Más dio por descargo tres mill maravedís que pagó al dicho Rodrigo de Toraja mostró carta de pago".

"Más da por descargo que pagó al dicho Rodrigo de Toraja seis ducados, mostró carta de pago".

"Más da por descargo que pagó a Rodrigo de Toraja doçe ducados para en pago de la obra de que mostró carta de pago".
Este maestro sigue unas trazas otorgadas en el año 1595 en León, posiblemente bajo la dirección del citado Baltasar Gutiérrez, sucesor de López de Rojas, por las que tenemos constancia se descargaron "beinte y quatro reales que llebó el que trazó la iglesia" 52 . Para fundamentar esta hipótesis, hemos de constatar el hecho de que el maestro Gutiérrez cobrase desde 1588 diversas cantidades por parte del cabildo catedralicio "en pago y remuneración de las muchas trazas que ha hecho para cosas que se le han pedido y de lo que ha dejado de ganar por no haber trabajado en la lonja" ${ }^{53}$.

Baltasar Gutiérrez trabajó activamente en la catedral, primero como aparejador y posteriormente como maestro mayor, cargo por el que cobraba la cantidad de 25.000 maravedís anuales, en obras como la construcción de los muros exteriores del trascoro entre los años 1573 y 1580, la realización de la cubierta del oratorio-sacristía en 1583 o la cubrición con nuevas bóvedas y sistemas de desagüe en 1604, a la vez que supervisaba otras muchas obras en la ciudad, como la ejecución que Juan del Ribero Rada llevaba a cabo, durante el verano de 1574, de la escalera prioral en la Real Colegiata de San Isidoro ${ }^{54}$. Esta tarea la compaginaba

${ }^{52}$ Ibídem, 17 de mayo de 1595, s.f. Mayordomo Andrés Díez. "Más da por descargo beinte y quatro reales que llebó el que trazó la iglesia".

"Más da por descargo que gastó en ir a León por el que trazó la iglesia".

"Más da por descargo del contrato de la iglesia quatro reales".

${ }^{53}$ La cantidad demandada era de 60 ducados. E. DÍAZ-JIMÉNEZ Y MOLLEDA, "Datos para la Historia del arte español", Revista de Archivos, Bibliotecas y Museos, tomo XLV, 1924, p. 424.

${ }^{54}$ Ibídem, p. 425. Sobre la escalera prioral de San Isidoro, véase: J. RIVERA BLANCO, Op. cit., pp. 135-141; M. D. CAMPOS SÁNCHEZ-BORDONA y M. CUESTA GARCÍA, "Los grabados del Prontuario de medallas de 1553 fuente de inspiración de la escalera prioral de San Isidoro de León", Lecturas de historia del arte. Ephialte, $\mathrm{n}^{\circ}$ 4, 1994, pp. 213-221; ÍDEM, "La escalera en la arquitectura leonesa del Renacimiento", Actas del IX Congreso Nacional C.E.H.A., tomo I, León, 1994, pp. 191-192; C. M. SEOANE FERNÁNDEZ, "La escalera prioral de San 
con una amplia experiencia en el diseño de obras y reparos para numerosas iglesias parroquiales, tal es el caso de las trazas dadas el 6 de enero de 1565 para la iglesia de Villacid de Campos o las que realiza con fecha 19 de octubre de 1597 en la iglesia de Gordoncillo ${ }^{55}$.

El proceso constructivo de la iglesia dio comienzo con el derribo de la madera anclada a las paredes del primer cuerpo construido, con el fin de levantar el muro de mampostería para la nave, anotándose cantidades de materiales y jornales superiores a los 4500 reales, a través de diversas cartas de pago reflejadas en las cuentas de 1596, 1598, 1600,1601 y $1602^{56}$.

Durante el trascurso de las obras a finales del año 1600, Rodrigo de Toraja, como maestro principal, es requerido para que "venga acavar la obra que tiene començada en su cargo aviendo la gran necesidad que ay y sino se le retire, otro maestro acave dando quenta a su señoría" 57 . Al año siguiente, ante el intento de cobrar al mayordomo de la fábrica cantidades superiores a las correspondientes con la marcha de las obras, se produjo la intervención del señor obispo, nombrando como peritos de las mismas al maestro de cantería de León, Pedro de Lla-

Isidoro de León", Ars Sacra, no 21, 2002, pp. 94-100; J. MARTÍNEZ MONTERO, Escaleras del Renacimiento Español. Símbolo y poder en el Burgos del siglo XVI, Burgos, 2014, pp. 47-48.

${ }^{55}$ E. DÍAZ-JIMÉNEZ Y MOLLEDA, Op.cit., pp. 421424; J. FUERTES SANTAMARTA, "Estudio históricoartistico de la iglesia parroquial de Gordoncillo", Tierras de León, $\mathrm{n}^{\circ}$ 48, 1982, pp. 32-44; A. PRIETO LÓPEZ, Historia de la villa de Gordoncillo, tomo II, León, 2007, pp. 84-90.

${ }^{56}$ AICR. $1^{\circ}$ Libro de fábrica, 10 de julio de 1596, s.f. Mayordomo Miguel Andrés. Ibídem, 20 de julio de 1598, s.f. Mayordomo Juan Lazo. Ibídem, 4 de febrero de 1600, s.f. Mayordomo Martín Bueno. Ibídem, $1^{\circ}$ Libro de fábrica, 18 de septiembre de 1601, s.f. Mayordomo Pedro Fernández. Ibídem, 1ํㅡㄴ Libro de fábrica, 23 de julio de 1602, s.f. Mayordomo Antonio Lazo.

${ }^{57}$ Ibídem, 23 de octubre de 1600, s.f. Visita del licenciado Pedro Gutiérreç, visitador del obispo de León D. Juan Alonso de Moscosso. nez y al de carpintería Rodrigo de Bedia, oriundo de Sahagún, quienes tasan la obra en novecientos y novecientos setenta y siete ducados respectivamente ${ }^{58}$.

Cuatro años antes, el propio Pedro de Llanez se obligaba junto al maestro de carpintería Pedro Álvarez de la Torre a la realización de la obra de la parroquial de Gordoncillo $^{59}$, a la vez que ocupaba el cargo de aparejador del maestro Felipe de la Cajiga, sustituyéndole al frente de la torre de la iglesia de Santa María del Mercado en el año $1598^{60}$, mientras que en 1613 aparecerá como arquitecto de la catedral, contratando las obras del hospital de San Martín en la ciudad de León ${ }^{61}$.

Finalmente y con motivo de la visita del licenciado Gaspar Maldonado a la iglesia en el verano de 1602, sabemos que la obra del cuerpo de la iglesia estaba "acabada y tassada por orden de su señoría y parece estar por revocar y mal acavado mucha parte de ella", por lo que ordena que no se pague más "hasta que se repare este daño y en lo que toca a la tasación parece que fue tasada en mil y ochocientos y setenta y siete ducados, mando al rector cura y mayordomo den relación a su señoría para que si fuere necesario se apelle de la dicha tasación porque según parece la obra fue excesiva la tasación y en esto ponga mucho cuidado el rector porque la iglesia no sea defraudada ni pague lo que no debe" 62 .

${ }^{58}$ Ibídem, 26 de mayo de 1601, s.f. "Tasación de la obra que hace Rodrigo de Toraja, obra de cantería en novecientos ducados y de carpintería en novecientos setenta y siete ducados, por Pedro de Llaneç maestro de cantería de León y Rodrigo de Bedia maestro de carpintería de Sahagún".

${ }^{59} \mathrm{~J}$. FUERTES SANTAMARTA, Op. cit., pp. 34-35; A. PRIETO LÓPEZ, Op. cit., pp. 87-89.

${ }^{60}$ M. GÓMEZ MORENO, Op. cit., p. 217.

${ }^{61}$ F. LLAMAZARES RODRÍGUEZ, "Trazas de los siglos XVI, XVII y XVIII en el Archivo Histórico Provincial de León", Tierras de León, no 36-37, 1979, p. 144.

${ }^{62}$ AICR. $1^{\circ}$ Libro de fábrica, 11 de julio de 1602 , s.f. Visita del licenciado Gaspar Maldonado por orden del obispo de León D. Juan Alonso de Moscosso. 


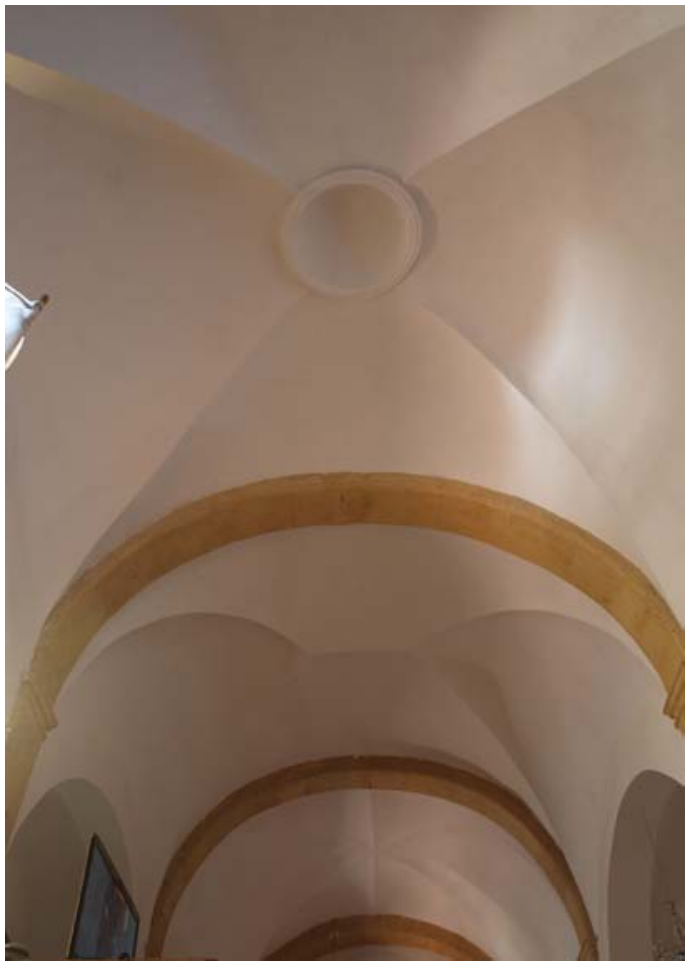

- Fig. 5. Abovedamiento de la nave de la iglesia de San Miguel de Cubillas de Rueda. Foto del autor.

Una vez finalizado el revoque de la nave y fallecido el maestro Gutiérrez, durante los años siguientes no se reflejan cargos importantes de la fábrica, a excepción de labores de retejo o aderezo de la capilla, sacristía y nave de la iglesia (Fig. 5) ${ }^{63}$. Es ahora cuando se da por concluida la obra, descargándose doce ducados al carpintero Gonzalo de la Cidra por hacer las puertas de la iglesia ${ }^{64}$; trabajo por el que en el segundo

${ }^{63}$ Ibídem, 6 de junio de 1611, s.f. Mayordomo Francisco Rodríguez. "Más da por descargo quatro reales de retejar la sacristía".

Ibídem, 4 de julio de 1612, s.f. Mayordomo Martín Bueno. "Más se le descargan sesenta reales que llevaron los ofiçiales por adereçar la capilla e sacristía de la iglesia".

Ibídem, 30 de mayo de 1614, s.f. Mayordomo Pablo de Villacorta. "Ytem da por descargo tres ducados que pagó a un offiçial por retexar la yglesia".

Ibídem, 13 de mayo de 1615, s.f. Mayordomo Santiago Fernández. "Más se le descargan nueve reales que llevó un cantero que gastó por recorrer el tejado de la yglesia y tapar unas ventanas".

${ }^{64}$ Ibídem, 13 de mayo de 1615, s.f. Mayordomo Santiago Fernández. de los libros de fábrica se anotan nuevos pagos correspondientes a los años 1618, 1619 y 1620 a cuenta de "las puertas y portal que fiço para la iglesia del dicho lugar" ${ }^{65}$.

A estos momentos pertenece la construcción de la portada principal de la iglesia; de corte clasicista, presenta una disposición a base de un arco de medio punto entre pilastras y remate de frontón triangular en cuyo tímpano se dispone una roseta (Fig. $6)^{66}$.

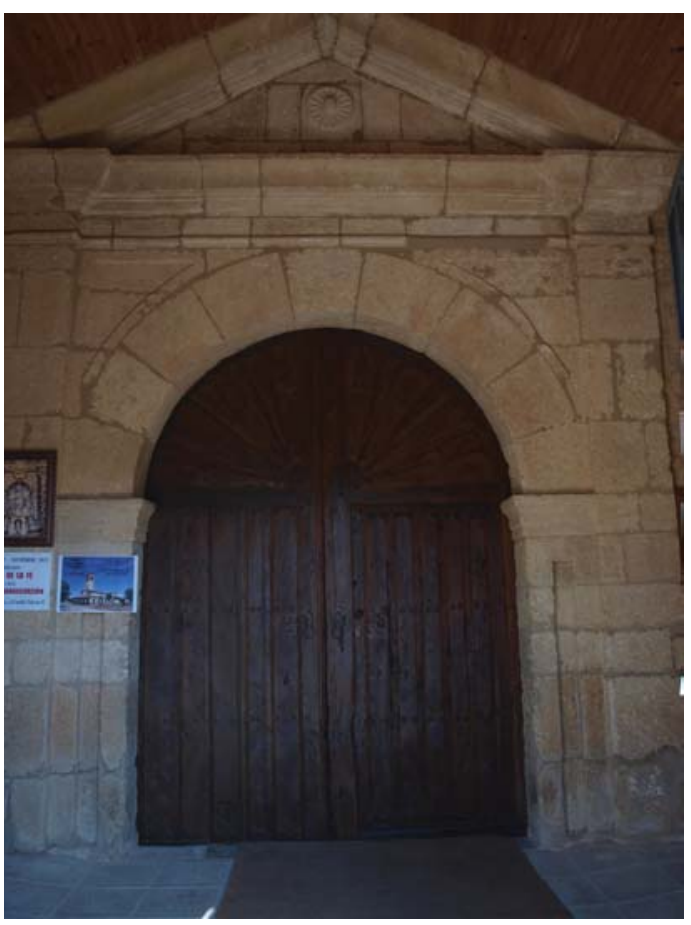

- Fig. 6. Portada de la iglesia de San Miguel de Cubillas de Rueda. Foto del autor.

${ }^{65}$ Ibídem. $2^{\circ}$ Libro de fábrica, 5 de julio de 1618, s.f. Ibídem, 30 de mayo de 1619, s.f. Ibídem, 29 de mayo de 1620 , s.f. "Más se le pagan en cuenta dieç y seis reales que dio en pago a Gonzalo de la Cidra carpintero con los quales se acabó de pagar todo lo que le devía la iglesia de los portales e puerta que para ella fiço". "Más doce reales que diose Francisco de las Caxigas carpintero por que retexo la iglesia".

${ }^{66}$ Campos Sánchez-Bordona la incluye junto a las portadas de las iglesias parroquiales de San Verismo en Alija del Infantado y Valdesaz como una tipología de tendencia al clasicismo de influencia escurialense. M. D. CAMPOS SÁNCHEZ-BORDONA, Juan de Badajoz..., p. 84. 


\section{LA NUEVA CUBIERTA DE LA CAPI- LLA MAYOR Y LA TRAZA DE FRAN- CISCO RIVAS}

En el año 1620, una vez terminada la obra de las puertas y portal de la iglesia, tiene lugar el derrumbe de la cubierta de la capilla mayor, por lo que la iglesia se ve obligada a contratar a un nuevo maestro para que se haga cargo de la obra; proceso que se prorrogará hasta el año 1624. El elegido fue el maestro de carpintería Francisco de Agüero junto a los carpinteros Francisco de Recibo y Gonzalo de la Cidra, quienes durante los años 1621, 1622 y 1625 reciben importes por sus trabajos para la cubrición de la capilla y acabado del portal ${ }^{67}$.

Sin embargo, las obras debieron suponer un enorme esfuerzo para la iglesia, ya que en 1636 todavía se estaba pagando al maestro ${ }^{68}$, y en 1648 tenemos constancia del endeudamiento en que se vio sumido el templo por el que "pagaba réditos de un censo de çiento y cinquenta ducados de plata de principal que se havia sacado para pagar al maestro que hiço la obra de la iglesia". Una cantidad que se iría saldando pro-

${ }^{67}$ AICR. ${ }^{2}$ Libro de fábrica, 15 de junio de 1621, s.f. “Más se le descargan cincuenta e un reales que dio a Francisco de Agüero a cuenta de lo que a de hacer por la obra de la iglesia".

"Más se le descargan del contrato de la obra de la iglesia que se hiço con Agüero".

"Más se le descargan doce reales que se dan a Cidra por quel vino a ver la obra que se ace en la iglesia y traza dello".

Ibídem, 1 de julio de 1622, s.f. "Más se le descargan veinte e tres ducados que pagó a Francisco de Recibo carpintero que fiço y devengó haçer a lo alto de la capilla que estaba hundida que por comisión del señor provisor de León se le dio a açer y adereçar".

Ibídem, 3 de junio de 1625, s.f. "Más se le descargan cinquenta e quatro reales que parece pago a Francisco de Agüero para su pago de la obra de la iglesia y portal".

"Más se le descargan siete reales al que parece dio al dicho Recibo que vino acabar el portal de la iglesia".

${ }^{68}$ Ibídem, 14 de junio de 1636, s.f. "Más pagar descargo quatrocientos y setenta y ocho reales que pagó a Francisco de Agüero maestro de carpintería de la obra que hiço en la dicha iglesia de que mostró carta de pago". gresivamente, según mandato del obispo D. Bartolomé Santos de Risoba, "de aquí al día de San Miguel deste presente año se quite y redima por lo menos la mitad y que en aviendo alcance bastante se quite y redima la mitad restante para que quede libre la dicha iglesia de pagar los réditos y las personas que la fiaron" 69 .

El 8 de noviembre de 1656, el canónigo de la catedral de León Juan de Balbuena, manda que "por obra de emprestado" las cofradías con sede en la parroquia, bajo la advocación de Nuestra Señora del Rosario y de San Roque, "puesto que tienen algunos alcances y están sobradas y no tienen necesidad en que lo gastar... y la iglesia parrochial tiene que redimir el censo referido, por tanto mando sumido que entre ambas le ayuden i den trescientos reales ciento y cinquenta cada una dentro de quatro meses"70.

En estos momentos se liquida la deuda contraída por la iglesia y se da por finalizada la obra constructiva, un proceso que perdurará durante más de un siglo, hasta que entre 1788 y 1789 el maestro Francisco Rivas da la traza de una obra que materializa el maestro astorgano Francisco Fernández, el carpintero Antonio Ferreras y los canteros llaniscos, Juan, Pedro y Gonzalo de Avin, quienes desmontan el tejado del cuerpo de la nave de la iglesia elevándola hasta el nivel de altura del arco de la capilla mayor a través de tres arcos pétreos de medio punto y otros seis de ladrillo que enlazan con ellos (Fig. 7) ${ }^{71}$.

${ }^{69}$ Ibídem, 19 de abril de 1648, s.f. Tercera visita del obispo de León D. Bartolomé Santos de Risoba.

${ }^{70}$ Ibídem, 8 de noviembre de 1656, s.f. Visita del canónigo de la catedral de León Juan de Balbuena.

${ }^{71}$ Este hecho se aprecia en la actualidad en el exterior del muro norte donde sobre la pared de mampostería se rehicieron pilares de ladrillo rellenándose los huecos con adobes.

AICR. $3^{\text {o }}$ Libro de fábrica, 6 de julio de 1788, s.f. Mayordomo Pedro del Reguero. "Y sesenta y dos reales que pago al Maestro Don Francisco Ribas que de orden de el Señor Obispo trazó la obra". 


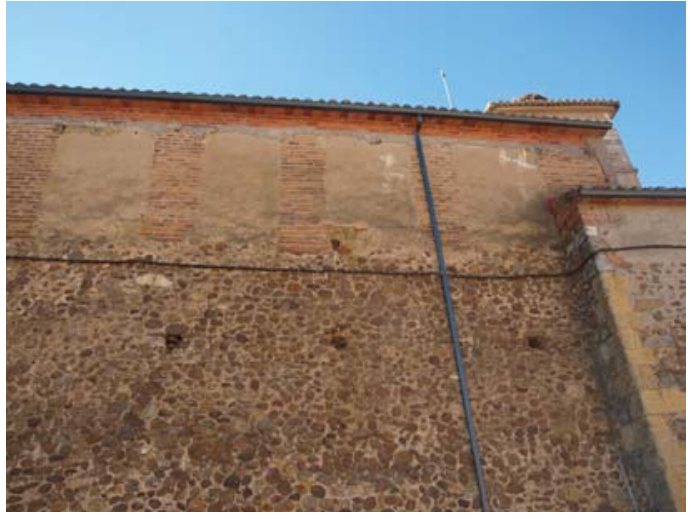

- Fig. 7. Detalle del muro exterior norte en el que sobre el muro de mampostería se aprecian los pilares de ladrillo y rellenos de adobes. Iglesia de San Miguel de Cubillas de Rueda. Foto del autor.

Tras esta ampliación, el nivel de altura de la nave se equiparaba al de la torre, por lo que se opta por hacerla más alta, levantándose entre 1792 y 1793 un doble cuerpo de campanas y aprovechándose para construir un soportal en el lado sur del templo ${ }^{72}$.

“Iten entrego a Juan de Avin el cantero a quenta de sus jornales, y de sus compañeros, veinte reales para San Pedro (a pagar en esa fecha)".

"Iten diez reales que se gastaron en el hospedaje de Don Francisco Ribas Maestro commisionado por el señor obispo para la dirección de la nueba obra, su criado y caballo".

Ibídem, 12 de agosto de 1789, s.f. Mayordomo Valentín Díez. "Iten se le pasan ciento y cinquenta reales de vellón que dio a Pedro de Avin y sus tres compañeros cinquenta de más jornales".

"Iten doscientos siete reales y medio que dio a Juan de Avin y sus tres compañeros a quenta de lo mismo".

"Iten pago a Antonio de Ferreras y su oficial doscientos ochenta reales y diez maravedíes a quenta de sus jornales"

"Iten pague a Gonzalo de Avin y sus dos compañeros a quenta de los jornales de la obra y poner esquinas en la torre sesenta y nueve reales".

${ }^{72}$ Ibídem, 25 de agosto de 1791, s.f. $3^{\text {a }}$ visita del obispo de León D. Cayetano Antonio Cuadrillero. "Item manda S. I. que se hagan los arcos del cuerpo de la iglesia para continuar las bóvedas levantando los machones desde el pie; y que dé el alzado correspondiente a la torre, respecto de ser baja, y no oírse bien las campanas".

Ibídem, 15 de noviembre de 1792, s.f. Mayordomo Marcelo Fernández. "Item de refeycionar la torre por sus cimientos con nuebas esquinas revocarla y rebocar todo el cuerpo de la iglesia, azer piso y paredes de la
Francisco Rivas fue uno de los artífices más activos en el círculo artístico leonés, cuyo trabajo en la capital se centró entre los años 1763 y 1791, tras la intervención de José García de Pumarino, en la finalización de la iglesia del convento de San Francisco ${ }^{73}$. Su actividad como maestro arquitecto contó con el impulso del obispo D. Cayetano Antonio Quadrillero y Mota, para quien dirigió la construcción del desaparecido hospicio de la ciudad desde 1786 hasta el año 1793, momento en que probablemente compaginara su labor al frente de la obra de la iglesia de los Descalzos ${ }^{74}$.

De su dirección en otras iglesias parroquiales de la provincia, está documentada hacia 1790 su participación en la iglesia de Oteruelo de la Valdoncina, mientras que el 16 de febrero de 1793 da la traza para la obra de la iglesia de Villazidayo, municipio ubicado en las inmediaciones de la parroquial de Cubillas de Rueda ${ }^{75}$.

Durante los años 1843 y 1844, se produjeron nuevas reformas en el interior del templo, tales como el levantamiento de las sepulturas alineadas en la capilla mayor y la construcción de una hoya a modo de osario

entrada del soportal cuatrocientos y veinte y dos reales y veinte i seis maravedís".

Ibídem, 4 de junio de 1793, s.f. Mayordomo Cruz Díez. "Primeramente se le recibe en descargo de su quenta quatro mil quinientos y cinquenta reales de vellón importe de los nueve arcos, saca de piedra y quatro mil ladrillos que costó la obra por el maestro de Astorga (Francisco Fernández) en esta iglesia y su porte".

${ }^{73}$ J. RIVERA BLANCO y M. C. RODICIO RODRÍGUEZ, "Una traza de Francisco de la Lastra y Francisco Martínez de Valle para el claustro del convento de San Francisco, de León", Tierras de León, no 21, 1975, p. 31.

${ }^{74}$ R. RODRÍGUEZ, Guía artística de León, León, 1925, p. 139; J. M. VILLANUEVA LÁZARO, La ciudad de León: del gótico-mudéjar a nuestros días (siglos XIV - XX), León, 1980, p. 182; J. C. PONGA MAYO, León perdido. Construcciones singulares desaparecidas en la ciudad de León de 1800 a 2000, León, 2009, pp. 89-91.

${ }^{75}$ M. URDIALES CAMPOS, “Léxico arquitectónico del siglo XVIII", Archivum, no 37-38, 1987-1988, pp. 462-470. En esta obra participan nuevamente el maestro astorgano Francisco Fernández y el cantero Gonzalo de Avín. 
para el depósito de los huesos, la elevación en la nave sur de la actual sacristía y el encalado de los muros $^{76}$.

Tras continuos retejos, el proceso constructivo se completó durante los años 1883 y 1884, cuando por valor de setecientas cuarenta y tres pesetas se acomete la obra "de enbovedar la iglesia, poner escalera al coro, reformar el alto y bajo, colocación de dos púlpitos y cosas laterales en la capilla mayor, picar todas las paredes y darlas un blanqueo a paño"77. El resultado es el de una nave cubierta por tres falsas bóvedas encamonadas de disposiciones cuatripartitas y octopartitas.

Finalmente, tras techarse en 1926 el baptisterio y eliminarse en 1946 la cal de los arcos de piedra ${ }^{78}$, se llevaron a cabo intervenciones de urgencia que culminaron en el año 1998 con las labores de levantado y nuevo entablado de la cubierta y tejado, junto a la sustitución de las ventanas y pavimentos interiores (Fig. 8) ${ }^{79}$.

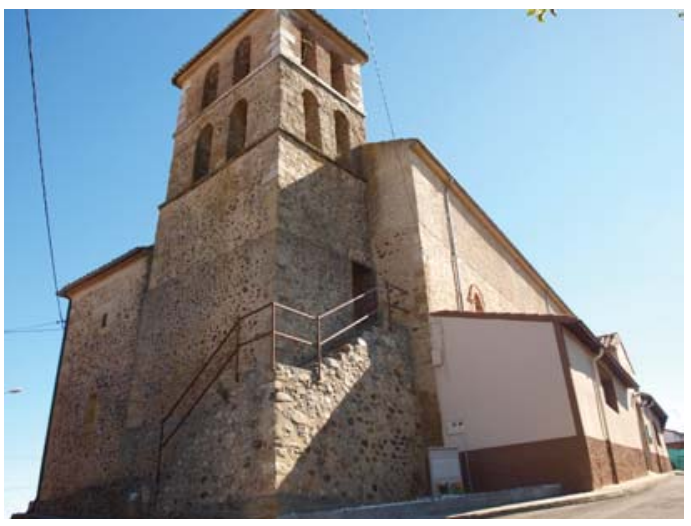

- Fig. 8. Vista exterior del baptisterio, torre y soportal lateral de la iglesia de San Miguel de Cubillas de Rueda. Foto del autor.
${ }^{76}$ AICR. $4^{\circ}$ Libro de fábrica, 12 de abril de 1844, s.f.

${ }^{77}$ Ibídem, 14 de abril de 1885, s.f. Ibídem, 25 de octubre de 1909, s.f.

${ }^{78}$ Ibídem, 22 de septiembre de 1926, s.f. Ibídem. $5^{\circ}$ Libro de fábrica, 1 de enero de 1947, s.f.
${ }^{79}$ M. I. BURÓN GARMILLA, Informe y valoración de la restauración de la iglesia de San Miguel Arcángel de Cubillas de Rueda (León), Sorriba del Esla (León), 23 de julio de 1998, pp. 2-4. 


\begin{tabular}{|c|c|c|c|c|}
\hline Maestro & Cargo & $\begin{array}{l}\text { Procedencia } \\
\text { Lugar / Obra }\end{array}$ & Obra & Fecha \\
\hline \multirow{2}{*}{ Pedro de Landeta } & \multirow{2}{*}{ Cantero } & \multirow{2}{*}{$\begin{array}{c}\text { Gautéguiz de Arteaga, } \\
\text { Vizcaya }\end{array}$} & \multirow[t]{2}{*}{ Capilla mayor } & 1562 \\
\hline & & & & $2 / 6 / 1563$ \\
\hline Fernando de Segura & Cantero & - & Capilla mayor & $2 / 6 / 1563$ \\
\hline \multirow{2}{*}{$\begin{array}{l}\text { Marcos Ibáñez de } \\
\text { Terliguiz }\end{array}$} & \multirow[t]{2}{*}{ Aparejador } & \multirow{2}{*}{$\begin{array}{c}\text { Monasterio de San Pedro } \\
\text { de Eslonza, León }\end{array}$} & \multirow[t]{2}{*}{ Capilla mayor } & $25 / 5 / 1564$ \\
\hline & & & & $18 / 6 / 1580$ \\
\hline \multirow[t]{4}{*}{ Joanes de Anderica } & \multirow[t]{4}{*}{ Cantero } & \multirow[t]{4}{*}{-} & \multirow[t]{4}{*}{ Capilla mayor } & $15 / 5 / 1566$ \\
\hline & & & & $5 / 6 / 1567$ \\
\hline & & & & $6 / 1567$ \\
\hline & & & & $6 / 6 / 1571$ \\
\hline \multirow[t]{2}{*}{ Marcos de Enderica } & \multirow[t]{2}{*}{ Cantero } & \multirow[t]{2}{*}{-} & \multirow[t]{2}{*}{ Capilla mayor } & $6 / 1567$ \\
\hline & & & & $10 / 3 / 1574$ \\
\hline \multirow[t]{2}{*}{ Joan López de Rojas } & \multirow{2}{*}{$\begin{array}{l}\text { Maestro de } \\
\text { obras }\end{array}$} & \multirow[t]{2}{*}{ Catedral de León } & Capilla mayor & $12 / 10 / 1570$ \\
\hline & & & & $10 / 3 / 1574$ \\
\hline Joanes de Lecica & Aparejador & Monasterio de San Pedro & Capilla mayor & $12 / 10 / 1570$ \\
\hline & & de Arlanza, Burgos & & $6 / 6 / 1571$ \\
\hline & & & & $11 / 2 / 1572$ \\
\hline & & & & $18 / 6 / 1572$ \\
\hline & & & & $4 / 7 / 1573$ \\
\hline Juan de la Cidra & Cantero & - & Sacristía & $10 / 7 / 1579$ \\
\hline Diego de Pando & Cantero & León & Sacristía & $3 / 6 / 1586$ \\
\hline & & & Obra & $10 / 9 / 1587$ \\
\hline & & & & $1 / 8 / 1591$ \\
\hline & & & & $4 / 8 / 1588$ \\
\hline Gonzalo de la Cidra & Carpintero & - & Sacristía & $3 / 6 / 1586$ \\
\hline & & & Puerta y portal & $6 / 3 / 1587$ \\
\hline & & & Obra & $2 / 7 / 1593$ \\
\hline & & & Puerta y portal & $13 / 5 / 1615$ \\
\hline & & & & $29 / 5 / 1620$ \\
\hline & & & Cubierta y portal & $15 / 6 / 1621$ \\
\hline Baltasar Gutiérrez & Maestro de & Catedral de León & Sacristía & $3 / 6 / 1586$ \\
\hline & obras & & Nave & $17 / 5 / 1595$ \\
\hline Bautista Vázquez & Entallador & León & Cajonería & $13 / 3 / 1589$ \\
\hline & & & & $7 / 8 / 1589$ \\
\hline & & & & $1 / 8 / 1591$ \\
\hline Rodrigo de Toraja & Maestro de & - & Cuerpo de la & $17 / 5 / 1595$ \\
\hline & carpintería & & iglesia & $10 / 7 / 1596$ \\
\hline & & & & $20 / 7 / 1598$ \\
\hline & & & & $4 / 2 / 1600$ \\
\hline & & & & $26 / 5 / 1601$ \\
\hline & & & & $18 / 9 / 1601$ \\
\hline & & & & $23 / 7 / 1602$ \\
\hline Francisco de Agüero & Maestro de & León & Iglesia y portal & $15 / 6 / 1621$ \\
\hline & carpintería & & & $3 / 6 / 1625$ \\
\hline & & & & $14 / 6 / 1636$ \\
\hline Francisco de Recibo & Carpintero & León & Iglesia y portal & $1 / 7 / 1622$ \\
\hline & & & & $3 / 6 / 1625$ \\
\hline Francisco Rivas & $\begin{array}{l}\text { Maestro } \\
\text { arquitecto }\end{array}$ & León & $\begin{array}{c}\text { Elevación de la } \\
\text { nave }\end{array}$ & $6 / 7 / 1788$ \\
\hline Antonio Ferreras & Carpintero & - & Elevación de la & $6 / 7 / 1788$ \\
\hline & & & nave & $12 / 8 / 1789$ \\
\hline Juan de Avin & Cantero & Nueva, concejo de Llanes & Elevación de la & $6 / 7 / 1788$ \\
\hline & & & nave & $12 / 8 / 1789$ \\
\hline Pedro de Avin & Cantero & Nueva, concejo de Llanes & $\begin{array}{c}\text { Elevación de la } \\
\text { nave }\end{array}$ & $12 / 8 / 1789$ \\
\hline Gonzalo de Avin & Cantero & Nueva, concejo de Llanes & $\begin{array}{c}\text { Elevación de la } \\
\text { nave }\end{array}$ & $12 / 8 / 1789$ \\
\hline Francisco Fernández & Maestro de & Astorga & Cuerpo de & $16 / 4 / 1788$ \\
\hline & obras & & $\begin{array}{c}\text { campanas y } \\
\text { soportal }\end{array}$ & $4 / 6 / 1793$ \\
\hline
\end{tabular}

- Fig. 9. Principales maestros que intervinieron en la obra de la iglesia de San Miguel de Cubillas de Rueda (1562-1793) 


\section{APÉNDICE DOCUMENTAL}

$-1-$

AICR. 1ํ Libro de fábrica (1563-1616) s. f. Mayordomo Pedro de Pendones.

Cubillas de Rueda, junio de 1567.

Mandamientos.

Capilla.

Y otrosi hallo al señor visitador que Joan de Alderica cantero, tiene tomada a haçer la capilla desta iglesia que conforme al contrato que está en este libro la abia ya de aber ya çerrado a dos años y aun que la iglesia tiene muchos materiales al pie de la obra no quiere entender en ella sino es en algunos inviernos muy pocos días quando yela y no se puede labrar con cal, por lo qual la obra forçosamente a de salir faltosa y las fianças que tiene dadas no bastan, e tiene reçebidos muchos maravedís, reçibe mucho daño la iglesia. Mandó el señor visitador que el cura y mayordomo den luego a esecutar el contrato contra el dicho ofiçial y sus fiadores y no le den más maravedís hasta que dé más fianças a contento de Bernardino Conde cura y del mayordomo y hasta que se obligue con fianças bastantes que por quinçe años de la ley de partida después que aya acabado la dicha obra no hará abertura ni sentimiento alguno y que la dará hecha e acabada para el mes de agosto primero venidero, so pena de pagar cinquenta ducados de pena que se le quiten de lo que uviere de aber pués la abia ya de aber acabado.

Yten que haga juntamente con la dicha capilla, altar y gradas altas y preyminentes y si el cura y mayordomo en esto fueren negligentes paguen dieç ducados para la dicha iglesia y más el daño que la viniere, y no permitan que en tiempo de invierno ni quando yela se labre en la dicha capilla.

Otrosí halló el señor visitador fraude contra la iglesia en el traer de la piedra, por- que traen pequeños carros y de ruin piedra muy caros, nombró por veedor de la dicha obra a Bernardino Conde cura, y mandó que el traer de la piedra y los demás materiales se echen en pregones y se trayan a vista del dicho retor, y el que de otra manera lo traxere no se le pague nada por los carros que ansi tragere.

Yten por que llamados los parroquianos a la visita y esamen de dotrina no quisieron venir sino tres dellos, condeno a cada uno en medio real para la fábrica desta iglesia o que cada uno traya un carro de piedra para la obra de la capilla dentro de un mes, sopena de excomunión y de los pagar con el doblo, y no se mandó comprar cosa ninguna hasta que la capilla se acabe.

$$
-2-
$$

AHDL. Protocolo de Juan Fernández de Vega, legajo 14, caja 9, s. f fo $^{80}$

Cubillas de Rueda, 12 de octubre de 1570 .

Contrato de la obra de cantería de la iglesia del lugar de Cubillas.

Sepan quantos esta pública escritura vieren como nos Juan Lópeç de Roxas, maestro de la obra de la santa yglesia de León, e yo Juan de Leçica, aparexador de la obra de señor San Pedro de Aslanza, vecinos de la cibdad de León como principales deudores y prestadores, e yo Bautista Bazquez escultor vezino de la cibdad de León como vuestro fiador e principal cumplidor y pagador, todos tres juntamente... (...) otorgamos e conoçemos por esta presente carta que nos obligamos, por nuestras personas e bienes muebles y rayçes avidos e por aber, de que demos de la obra que la iglesia parroquial de señor San Miguel del lugar de Cubillas

\footnotetext{
${ }^{80}$ Nuestro agradecimiento a la Dra. Losada Varea por su revisión a la transcripción del presente documento.
} 
tierra de Rueda tienen comenzada a haçer Marcos de Terliguiz e Juanes de Enderica canteros defuntos, y ques los cimyentos y partes de paredes hasta los capiteles de la capilla mayor de la dicha yglesia, haremos y acabaremos de azer la dicha capilla hasta la poner en perfeccion, de suerte que esté acabada en lo que toca a la cantería a vista de oficiales, nombrados los unos por parte de la dicha iglesia y los otros por parte de nos los dichos oficiales, de suerte que la dicha obra questá fecha y la que nos hicieremos en la dicha capilla será fuerte y firme, y puesta en la raçon y arte que se requiere, sopena que no la haciendo fuerte y firme y a vista de oficiales que la hayamos de derrocar y bolber açer de nuevo a nuestra costa e misión a vista de los oficiales según dicho es, ansi la qual dicha obra daremos fecha y acabada de suerte que sobre ella se pueda cargar la madera de la dicha capilla e texado della dentro de un año de la firma desta carta, e ordeno que no dando fecha y acabada la dicha obra según dicho es para que dicho tiempo, nos obligamos de que daremos en limosna para la dicha yglesia setenta ducados de oro, por lo qual no se pueda dar a executar como por el deudo principal, e decimos que si al dicho tiempo no dieremos acavada la dicha obra, a nuestra costa puedan buscar ofiçiales que acaven la dicha obra según está deletrado, los quales ansymismo aunque se nos an de poner al pie de la dicha obra todos los materiales nezesarios para acabar la dicha obra a costa de la dicha yglesia y que se nos an de acudir después de comprados los dichos materiales con todos los maravedís e pan que la dicha yglesia tuviere, quedando para luminaria della lo nezesario, e conque si por parte de la dicha yglesia no se nos dieren los materiales e pan e dinero que la dicha yglesia tuviere, no entramos en las penas arriba contenydas, e yo Juan de Baldeón mayordomo que al presente soy de la dicha yglesia de San Miguel del dicho lugar de Cubillas que a lo que dicho es presente estado, digo que por birtud de la liçencia que ay para haçer la dicha obra firmada del señor probisor deste obispado obligo los bienes e rentas de la di- cha yglesia muebles raíces ávidos e por aver de que poner a pie de la dicha obra todos los materiales que fueren necesarios para la dicha obra de la dicha capilla a costa de la iglesia, y además de lo susodicho después de puestos todos los dichos materiales acudiré con la renta que la dicha yglesia tuviere a los dichos ofiçiales, y además de lo susodicho de los bienes de la dicha yglesia pagaré todos los demás maravedís en que dicha obra fuese tasada conforme la yglesia estubiere e fuere rentando, quedando para la luminaçión della lo necesario, y en todo lo demás que de suso se contiene en esta escritura açer lo qual todo que dicho está, cumpliré y por haçer de los bienes de la dicha yglesia llanamente y sin pleito alguno, e para que nos ambas las dichas partes ansi guardemos e cumplamos por esta carta y con ella, rogamos, pedimos e damos todo nuestro poder cumplido y el de la dicha iglesia cada uno a su jurisdiçión eclesiástica y seglar destos reynos y señoríos de su mayorazgo, la jurisdiçión y señorio de las quales y de cada una dellas, nos sometemos conjuntas personas... (...) otorgada en la ciudad de León a doçe días del mes de octubre de myl e quinientos e setenta años... (...) y los dichos oficiales e fiadores firmaron de su nombre e por el dicho mayordomo que dixo que no savía escribir de su ruego lo firmó Thomé de Çelis a los quales otorgamos yo el escrivano doy fee conozco.

Juan de Leçica; Bautista Bazquez; Juan López de Rojas; Thomé de Çelis.

Pasó ante mí:

Juan Fernández de Vega.

$-3-$

AICR. 1ํㅡㄴ Libro de fábrica (1563-1616) s. f. Mayordomo Antonio Martínez.

Cubillas de Rueda, 17 de marzo de 1574. 
Visitaçion de la iglesia parrochial de Sant Miguel del lugar de Covillas hecha por el muy magnífico y muy reverendo señor bachiller Joan Gutiérreç de Villanueva, arcipreste de Cervera, visitador general en el obispado de León por el muy ilustre y reverendísimo señor Don Joan de Sant Millán, obispo de León del consejo de la magestad real en dieç y siete del mes de março de mill y quinientos y setenta y quatro años.

Descargo.

Canteros tasación de la capilla.

E luego el señor visitador hiço parescer antesí la tasación de la capilla que en esta iglesia hiçieron Joan López de Rojas y Marcos de Denderica canteros, y hallo que fue tasada la hechura de la capilla mayor en ciento y treinta y tres mill maravedís.

Pagas 83.107.

E por las pagas hechas por los mayordomos a los dichos canteros pagadas en las cuentas deste libro, le constó que an rescibido hasta oy dia en quenta de la capilla ochenta y tres mill y çiento y siete maravedís.

Réstaseles deviendo 49.893.

Por manera que se resta deviendo a los dichos canteros, para les acavar de pagar los dichos çiento y treinta y tres mill maravedís en que se tasó la dicha capilla, quarenta y nueve mill y ochoçientos y noventa y tres maravedís.

Los quales mando el señor visitador los den y paguen a los canteros y no otros algunos, so pena que el mayordomo que más maravedís le diere los pagara de su cassa y no les será tomado en quenta y pagará más quatro ducados de pena... (...)

\section{Blanquear.}

Iten mando el señor visitador que antes que los andamios se quiten, se blanquee la capilla, porque después costará mucho tornar a poner los andamios y que se blanquee sin pintura ni pinçel alguna, porque sea a menos costa y más vistosa.
Aguas.

Iten por el agua que cae de los tejados de la capilla, no puede correr afuera por los montones de tierra que están adelante y podría venir daño y hollar los estrivos y abrir la obra que es muy pesada, y mandó el señor visitador que la tierra que está cerca de las paredes se quite y se allane, de tal manera que el agua que cayere se recoja afuera y no se reprense nada a par de las paredes, lo qual haga haçer al mayordomo dentro de un mes sopena de dos ducados para la fábrica de la iglesia.

\section{Gradas.}

Iten mandó el señor visitador que luego se entienda en quitar la pared que está entre la iglesia y la capilla y que se hagan quatro o cinco gradas vien hechas, y sobre ellas el altar mayor que esté alto y preheminente de doçe palmos de largo, y que se pase el retablo y se asiente luego en la dicha capilla y se diga misa en ella y ésto se haga con toda brevedad, sopena que si el mayordomo fuere en esto negligente pague quatro ducados de pena y que el cura le evite de las horas hasta que lo haga haçer.

$$
-4-
$$

AICR. 1ํ Libro de fábrica (1563-1616) s. f. Mayordomo Andrés Verdugo.

Cubillas de Rueda, 8 de noviembre de 1576.

Visitaçion de la iglesia parrochial de Sant Miguel del lugar de Covillas hecha por el muy magnífico y muy reverendo señor bachiller Joan Gutiérreç de Villanueva, arcipreste de Cervera, visitador general en el obispado de León por el muy ilustre y reverendísimo señor Don Joan de Sant Millán obispo de León, en ocho días del mes de noviembre de mill y quinientos y setenta y seis años. 
Capilla tasación.

E luego el señor visitador vio la tasación de la capilla mayor que en esta iglesia hiçieron Joan López de Rojas y Marcos de Denderica y halló que fue tasada la dicha capilla en ciento y treinta y tres mil maravedís.

Pagas canteros.

E por las pagas y partidas en este libro le constó que an recibido hasta oy dia ochenta y nueve mill y nueveçientos y siete maravedís.

Resta.

Por manera que se le restan debiendo para les acabar de pagar la dicha capilla quarenta y tres mill y noventa y tres maravedís y no más.

Los quales mando los den y paguen a los dichos ofiçiales y no otros algunos, sopena que el mayordomo que más maravedís les diere los perderá y no les será tomado en quenta y pagarán más diez ducados de penas.

$-5-$

AICR. 1ํ Libro de fábrica (1563-1616) s. f. Mayordomo Juan de Vega.

Cubillas de Rueda, 15 de noviembre de 1581.

Visitaçión de la yglesia parrochial del señor San Miguel del lugar de Cubillas tierra e jurisdiçión de la villa de Rueda, fecha por el muy magnífico e muy reverendo señor liçenciado Luis de Rabanal, bisitador general en todo el obispado de León por el muy reverendo señor Don Francisco Truxillo por la graçia de Dios y de la santa yglesia de Roma obispo del dicho obispado... (...) a quinçe días del mes de nobiembre de mill e quinientos e ochenta e un años.

Tasación de la capilla de cantería.
Iten falló el señor visitador que en la visita pasada del año setenta y seis, el bachiller Juan Gutiérrez, visitador que berificó la tasaçión de la obra de cantería de la capilla mayor que fiçieron en esta iglesia Juan López de Roxas e Marcos de Enderica cantero y sus compañeros. E falló que fue tasada en ciento y treinta y tres mill maravedís.

Pagas a los canteros hasta esta visita.

Iten que hasta la dicha visita tenían rescevido los susodichos ochenta y nuebe mill y nobecientos y siete maravedís. E desde la dicha visita para acá hasta esta visita, quarenta y tres mill e çiento y siete maravedís, que suma por monta en todo lo que hasta agora an rescevido los dichos canteros, çiento y treinta e quatro mill e catorce maravedís.

Tienen rescevido de más los canteros.

De manera que tienen rescevido de más los dichos canteros de los çiento y treinta y tres mill maravedís en que fue tasada la dicha capilla mill y catorce maravedís, según se tomó cuenta y paresçe por las pagas que se an hecho a los dichos canteros.

Condena a Fernando Fernándeç que pagó de más a los canteros.

E porque Fernando Fernándeç, mayordomo que fue el año pasado de mill e quinientos e ochenta que fice el postrero, mayordomo que acabó de pagar a los dichos canteros con treçe mill e ochoçientos y treinta y seis maravedís, que en tres partidas son descargo, dijo que abia pagado a Ana de Robles, mujer que quedó del dicho Juan López de Rojas, vecina de la çiudad de León, e son a çinquenta de las pagas que a los dichos canteros se abían hecho, le pagó los dichos mill e catorçe maravedís de más de lo que abían de aber. Le condenó el señor visitador a que los pague a la iglesia e los cobre del susodicho Fernando Fernándeç, y en las primeras quentas que sean tomadas se le carguen juntamente con el demás cargo que se le hiçiese... (...) 